\title{
Effect of Seed Priming Methods on Germination of Indian Jujube (Ziziphus mauritiana. LAM) in Northern Guinea Savanna Ecological Zone of Nigeria
}

\author{
Sodimu, A. I*, Usman, M.B, Osunsina, O, Lapkat,G.L, Likita, M.S and Okechalu, S.O \\ Federal College of Forestry Mechanization, Forestry Research Institute of Nigeria, P.M.B 2273, Afaka- Kaduna, Nigeria
}

*Corresponding Author

Sodimu A. I

\author{
Article History \\ Received: 30.07 .2020 \\ Accepted: 07.08 .2020 \\ Published: 13.08.2020
}

\begin{abstract}
Effect of seed priming methods on germination of Indian Jujube (Ziziphus mauritiana. LAM) In Northern Guinea Savanna Ecological Zone of Nigeria was studied at the Federal College of Forestry Mechanization, AfakaKaduna Nursery. The treatments consisted of Boiled water $\left(100^{\circ} \mathrm{C}\right)$ for 10 minutes, 15 minutes and 20 minutes; diluted sulphuric acid $\left(\mathrm{H}_{2} \mathrm{SO}_{4}\right)$ soaking time for 10minutes, 15 minutes and 20 minutes; Seed scarification (sand papering and cracking) and control. Ten (10) seeds from each of the treatments were sown in germination box containing sterilized river bank sand and replicated three (3) Times. The experimental design adopted was a Completely Randomized Design (CRD). Data from germination were analyzed using descriptive statistics and Analysis of Variance (ANOVA) at 0.05 level of probability. Results revealed that the seed of Indian jujube (Ziziphus mauritiana) seeds scarified showed a significant germination percentage $(95.20 \pm 7.34)$ than any other methods, followed by soaking in sulphuric acid $\left(\mathrm{H}_{2} \mathrm{SO}_{4}\right)$

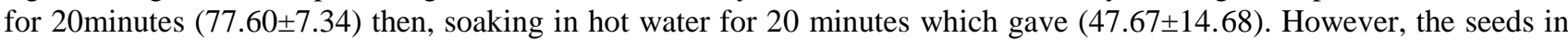
the control were significant $(\mathrm{P}>0.05)$ lower in germination percentage (3.20 \pm 7.34$)$ than any other methods applied. Therefore, it is concluded that for effective, sustainable and fast multiplication of germination of Indian jujube (Ziziphus mauritiana) seeds in the tree nursery scarification methods should be adopted.
\end{abstract}

Keywords: Seed Priming, Guinea Savanna, germination, Multiplication, Sustainable.

\section{INRODUCTION}

Many seeds have difficulty in germination such that their propagation is adversely affected by seed coat dormancy leading to poor growth potential [1]. In several species, seeds germinate rather slowly, and at times even fail to germinate [2]. This is because the seeds easily loose viability exhibited through the evolution of an oxygen and water to the embryo [3]. One of the major problems associated with afforestation programmes in the tropics is the fact that most tropical forest tree seeds exhibit one form of dormancy or another [4]. The conditions necessary to allow seeds to break dormancy and germinate can be highly variable among species, within a species, or among seed sources of the same species [5]. Hard seed coat, type and sizes have been identified by [6] as some attributes which affect germination and growth of indigenous species and sometimes, This poor germination ability may be due to seeds dormancy or insect attack, some of such indigenous plant includes Ziziphus mauritiana (Magarya) among others However, if stored for a long time most seed lose their viability, since they are not normally sown, until sometimes after collection, so pregermination treatment is important to prevent wasting time and money in sowing seeds with poor germination ability. The pre-treatment of these species seeds are necessary to enhance accessibility of water and oxygen into the seeds and to obtain optimum germination and improved performance for plantation establishment.

Indian jujube (Ziziphus mauritiana) is a shrub or small thorny tree belonging to the family Rhamnaceae. The tree that can grow to a height of 3-15 m. Deciduous or almost evergreen, Indian jujube has an erect or spreading habit [79]. It has a deep taproot [10]. The trunk is around $40 \mathrm{~cm}$ in diameter, covered with a dark grey or dull black, irregularly fissured bark [7]. The branches are numerous and drooping. The twigs are tomentose. The spines are solitary or borne in pairs at the base of the leaves, 5 to $7 \mathrm{~mm}$ long [11]. In cultivated Indian jujube, the spines may be absent [12]. The leaves are simple, alternate, ovate, and $2-9 \mathrm{~cm}$ long with 3 conspicuous longitudinal veins. The upper surface of the leaves is

Copyright @ 2020: This is an open-access article distributed under the terms of the Creative Commons Attribution license which permits unrestricted use, distribution, and reproduction in any medium for non commercial use (NonCommercial, or CC-BY-NC) provided the original author and source are credited. 
dark glossy green and the lower one is densely hairy $[11,10]$. This dense silky underside helps distinguish Indian jujube from Chinese jujube (Ziziphus jujuba Mill.) [10]. The fruit skin may be smooth or rough, glossy, yellowish to reddish or blackish. The flesh is white, juicy, slightly acid to sweet, turning mealy when fully ripe [11]. The stone is single, central, hard, oval or oblate, with a rough surface. It contains 2 elliptic, brown seeds, $6 \mathrm{~mm}$ long [10].Indian jujube can be grown in semi-arid and arid regions as it thrives under very dry conditions. In the Sahelian zone, Indian jujube is one of the most persistent trees, like Acacia raddiana and Balanites aegyptiaca [13].

Indian jujube is a multi-purpose tree mainly grown for its fruits. It starts bearing fruits 6-8 years after planting, and yield increases until the tree is 15-20 years old [9]. The fruit is edible and can be eaten fresh, dried like dates, candyied, salted or pickled [11,9]. It can be processed into flour meal, paste, juice, syrup or an alcoholic beverage [11]. It is a good source of carotene, vitamins A and C, and fatty oils [7]. Young leaves are edible and are cooked as a vegetable in Indonesia. Fruits and bark are used to make dye and medicinal preparations [7,9]. Indian jujube wood is reddish, fine-textured, hard and durable. It can be used in rural house construction, posts and tool manufacturing. It makes excellent firewood. The Indian jujube tree hosts lac insects, and is also fodder for the tasar silkworm that makes high-prized silk in India [7]. It is a minor source of pollen for bees [7]. A potential agroforestry species, this thorny tree can grow to provide windbreaks and living fences. It is browsed by livestock and its leaves are nutritious fodder for sheep and goats $[14,7,9]$.

However, to perpetuate all these uses of the species, some measures must be taken in view of the degrading vegetation due to deforestation, agricultural and pastoral pressure on forested land. The measures to be taken include; identifying, collecting seeds, pre-testing the seeds, preparing the potting mixture, sowing and watering of seeds, tending the seedlings in the nursery, site preparation and seedling plantation [15]. In arid and semi-arid regions, desert encroachment due to excessive deforestation led to dwindling agricultural field coursed by the resultant poor soil status [16]. Consequently, the land is no longer able to meet the upsurge in demand for forest products, food, fodder, fuelwood and other minor forest products. Therefore, there is an urgent need to enlighten the local people for quick move towards methods of pre germinating, raising and tending of indigenous species so that most of them will not go into extinction because their population is already being threatened by anthropogenic activities in varies degrees. Meanwhile the neglect of these species leads to loss of information on more efficient methods of pretreating indigenous seeds to induce quick germination of tree species for plantation establishment.

The major objective of the study is to determine the effect of different seed priming methods on germination of Ziziphus mauritiana. In Northern Guinea Savannah Ecological zone of Nigeria.

\section{Materials ANd Methods}

The study was carried out in the nursery of the Federal College of Forestry Mechanization, Forestry Research Institute of Nigeria, Afaka- Kaduna, Kaduna state, Nigeria. It lies between latitude $10^{\circ} 37^{1}$ North and longitude $7^{\circ} 47^{1}$ East [17]. The college is situated in the Northern Savannah ecological zone on $613 \mathrm{~m}$ above sea level. The average annual temperature is $25.2{ }^{\circ} \mathrm{C}, 77.3{ }^{\circ} \mathrm{F}$. Rainfall is approximately $100 \mathrm{~cm}$ annually with the lowest mean monthly relative humidity reaching up to about $29 \%$. It is an open woodland with tall grasses of about $(1 \mathrm{~m}-3 \mathrm{~m})$ in height usually with broad leaves [18].

\section{Treatments and Experimental Design}

Treatments consisted of Boiled water $\left(100^{\circ} \mathrm{C}\right)$ for 10 minutes, 15 minutes and 20 minutes; diluted sulphuric acid $\left(\mathrm{H}_{2} \mathrm{SO}_{4}\right)$ soaking time for 10 minutes, 15 minutes and 20 minutes; Seed scarification and control. Ten (10) seeds each were soaked in Three (3) Treatments arranged in Completely Randomized Design (CRD). Ten (10) seeds from each of the treatments were sown in germination box containing sterilized river bank sand and replicated three (3) Times.

\section{Procedure for experimentation}

Experiment 1 (Hot Water Treatment):

Water was boiled for $100^{\circ} \mathrm{C}$ and seeds were added to the boiled water and allowed it to soak for three different times 10, 15, and 20 minutes. Then the seeds were removed and allowed to cool.

\section{Experiment 2 (Acid treatment)}

The seeds were soaked in diluted sulphuric acid $\left(\mathrm{H}_{2} \mathrm{SO}_{4}\right)$ for three different periods $(10,15$, and 20minutes). After the soaking the seeds were removed, washed and rinsed in running tap water to remove any remaining acid.

\section{Experiment 3 (Scarification Treatment)}

Mechanical scarification was done by carefully filling the seeds with sand paper until the seeds begins to crack. Caution must be taken while carrying out this scarification process not to damage the embryo of the seeds. 


\section{Experiment 4 (Control):}

Indian jujube (Ziziphus mauritiana) seeds sown without any pre-germination treatment served as control.

\section{Data Collection}

Seeds Germination was monitored for fourty days (40 days) and data were collected on Days of emergence (Number of days taken for first emergence), rate of germination (Number of seeds germinated) and germination percentage. Percentage seed Germination (PG) and Germination Rate (GR) were estimated with the following equations:

$$
\mathrm{GP}=\underline{\mathrm{SG}} \times 100
$$
equation (1)

Where:

$$
\begin{aligned}
& \mathrm{GP}=\text { Germination percentage } \\
& \mathrm{SG}=\text { Seed germinated } \\
& \mathrm{TS}=\text { Total number of seed germinated }
\end{aligned}
$$

$$
\mathrm{GR}=\underline{\mathrm{GP}}
$$

Where:

$$
\begin{aligned}
& \mathrm{GR}=\text { Germination rate } \\
& \mathrm{GP}=\text { Germination percentage } \\
& \mathrm{T}=\text { Time taken }
\end{aligned}
$$

\section{Data Analysis}

Data from germination were analyzed using descriptive statistics and Analysis of Variance (ANOVA) with SPSS statistical package [19] and means were compared using Least Significant Difference (LSD) test at (P>0.05) level.

\section{RESULTS AND DiSCUSSION}

Effect of hot water treatment on Indian jujube (Ziziphus mauritiana) germination:

The percentage germination of seeds soaked in $100^{\circ} \mathrm{C}$ hot water (Table-1) for 20 minutes was significantly higher and gave percentage germination of $(47.67 \pm 14.68)$ than those of all other hot water treatment of 10 minutes and 15 minutes. The seed treated with hot water at $100^{\circ} \mathrm{C}$ for 10 minutes gave germination percentage of $(32.33 \pm 7.34)$ and for 15 minutes gave $(37.64 \pm 7.34)$. The results from this work is in agreement with the finding of [20] who noted that hot water is the most effective way of improving seed coat permeability in seeds of Leucaena leucocephala. But contrary to the work of [21] who stated that seeds of Calliandra prototricensis failed to germinate in hot water. However [22], reported that soaking of Azadrachta indica seeds for one and two hours resulted in increasing rate of seeds germination supporting the work of [23] on the seeds of Adansonia digitata.

Table-1: Germination of Indian Jujube (Ziziphus mauritiana) in Hot Water

\begin{tabular}{|l|l|l|l|}
\hline $\begin{array}{l}\text { Treatment } \\
\text { (Minutes) }\end{array}$ & $\begin{array}{l}\text { Mean Number of Days for } \\
\text { First Emergence }\end{array}$ & $\begin{array}{l}\text { Mean Number of Seeds } \\
\text { Germinated }\end{array}$ & $\begin{array}{l}\text { Germination } \\
\text { Percentage }\end{array}$ \\
\hline 10 & $15.00 \pm 0.00^{\mathrm{a}}$ & 0.3233 & $32.33 \pm 7.34^{\mathrm{c}}$ \\
\hline 15 & $16.83 \pm 0.65^{\mathrm{a}}$ & 0.3764 & $37.64 \pm 7.34^{\mathrm{c}}$ \\
\hline 20 & $15.00 \pm 0.00^{\mathrm{a}}$ & 0.4767 & $47.67 \pm 14.68^{\mathrm{c}}$ \\
\hline SE \pm & 0.00 & & 0.00 \\
\hline
\end{tabular}

Mean with the same letters along the same column are not significant different from each other $(P>0.05)$

\section{Effect of sulphuric acid treatment on Indian jujube (Ziziphus mauritiana) germination:}

The percentage germination of seeds treated with 20 minutes, soaking of $\mathrm{H}_{2} \mathrm{SO}_{4}$ was significantly higher $(\mathrm{P}>$ $0.05)$ for $(77.60 \pm 7.34)$ than those for 10 minutes, that had $(72.10 \pm 11.34)$ and for 15 minutes which gave $(75.20 \pm 12.34)$ (Table-2) Twenty (20) minutes soaking in $\mathrm{H}_{2} \mathrm{SO}_{4}$ gave the highest germination percentage of $77.66 \pm 7.65$, though there were no significant differences between the other 2 level $(10,15)$ which gave $72 \%$ and $75 \%$ respectively. This result is in accordance with the work of [24] on Enterolobium cyclocarpum, Pilostigma reticulatum and [25] on Adansonia digitata who noted that treatment with acid significantly promoted germination of the seeds. This finding is also similar to prior reports of [26] that acid treatment of seeds removes the waxy layer of the seed coat by chemical decomposition of the seed coat components that, the faster the rate of germination. While [1] also observed that treatment with sulphuric acid for six (6) to twelve (12) hours led to germination of more than $90 \%$ of seeds within twenty (20) days of sowing. 
Agbogidi O. M et al., [27] noted that soaking of Dacyodes edulis seed in sulphuric acid $\mathrm{H}_{2} \mathrm{SO}_{4}$ reduce the germination period considerable and concluded that it was the best method, though, dangerous. Therefore, when using safety precaution is very important.

Table-2: Germination of Indian Jujube (Ziziphus mauritiana) in Sulphuric Acid $\left(\mathrm{H}_{2} \mathrm{S0}_{4}\right)$

\begin{tabular}{|l|l|l|l|}
\hline $\begin{array}{l}\text { Treatment } \\
\text { Minutes) }\end{array}$ & $\begin{array}{l}\text { Mean Number of Days for } \\
\text { First Emergence }\end{array}$ & $\begin{array}{l}\text { Mean Number of Seeds } \\
\text { Germinated }\end{array}$ & $\begin{array}{l}\text { Germination } \\
\text { Percentage }\end{array}$ \\
\hline 10 & $15.00 \pm 0.00^{\mathrm{a}}$ & 0.721 & $72.10 \pm 11.34^{\mathrm{b}}$ \\
\hline 15 & $16.43 \pm 1.25^{\mathrm{a}}$ & 0.752 & $75.20 \pm 12.34^{\mathrm{b}}$ \\
\hline 20 & $12.00 \pm 0.00^{\mathrm{ab}}$ & 0.776 & $77.60 \pm 7.34^{\mathrm{b}}$ \\
\hline $\mathrm{SE} \pm$ & 0.00 & & 16.00 \\
\hline
\end{tabular}

Mean with the same letters along the same column are not significant different from each other $(P>0.05)$

\section{Effect of Mechanical Scarification treatment on Indian jujube (Zizizphus mauritiana) germination}

The germination percentage of all the scarified seeds had germination percentage of (95.20 \pm 7.34$)$ (Table-3). Z. mauritiana scarified with sand paper overcome dormancy and gave 93.33 \pm 5.77 germination. Mechanical scarification on the seeds of $Z$. mauritiana cause early germination (11 days) as against their normal period of dormancy which is $35-40$ days. This is in agreement with earlier findings of [20] who observed that mechanical scarification is an efficient way of improving seed coat permeability of Pterocarpus angolensis and Leucaenia leucocephala seeds. Tomlinson $\mathrm{H}$. N et al., [28] also observed that seed dormancy resulting from an impermeable seed coat may be overcome by peeling off the coat. According to [27], who noted that scarification gave the highest mean percentage germination than either immersion in hot water or sulphuric acid, but there was no significant difference between one scratche with sand paper (96.67\%) and two scratches with sand paper (86.67\%) on seeds for Acacia sieberiana but Acacia seyel recorded $83.33 \%$ and for one and two scratches. This result also agrees with earlier report by [22] on seed germination of Pterocarpus osun when subjected to filling and clipping at their micropyle end. Similarly [22], stated that seeds of Pinus bruatia germination improved when it was rubbed with sandpaper at the micropyle end. Duguma B et al., [20] affirmed that seed scarification is the most effective way of improving seed coat permeability in seed of Leucaenia leucocephala.

Table-3: Germination of Indian Jujube (Ziziphus mauritiana) in Scarification

\begin{tabular}{|l|l|l|l|}
\hline $\begin{array}{l}\text { Treatment } \\
\text { (Minutes) }\end{array}$ & $\begin{array}{l}\text { Mean Number of Days for } \\
\text { First Emergence }\end{array}$ & $\begin{array}{l}\text { Mean Number of Seeds } \\
\text { Germinated }\end{array}$ & $\begin{array}{l}\text { Germination } \\
\text { Percentage }\end{array}$ \\
\hline & $16.43 \pm 1.25^{\text {a }}$ & 0.952 & $95.20 \pm 7.34^{\text {a }}$ \\
\hline SE \pm & 0.734 & & 0.367 \\
\hline
\end{tabular}

Mean with the same letters along the same column are not significant different from each other $(P>0.05)$

Effect of untreated seed on Indian jujube (Ziziphus mauritiana) germination:

The lowest germination percentage was found for seeds in the untreated control which gave 3.20 \pm 7.34 (Table4). This was not in agreement with results of work reported by [29] where they found that control untreated seeds of Balanitesa egyptiaca had significantly higher germination then seeds boiled in hot water.

Table-4: Germination of Indian Jujube (Ziziphus mauritiana) in Control

\begin{tabular}{|l|l|l|l|}
\hline $\begin{array}{l}\text { Treatment } \\
\text { (Minutes) }\end{array}$ & $\begin{array}{l}\text { Mean Number of Days } \\
\text { for First Emergence }\end{array}$ & $\begin{array}{l}\text { Mean Number of } \\
\text { Seeds Germinated }\end{array}$ & $\begin{array}{l}\text { Germination } \\
\text { Percentage }\end{array}$ \\
\hline & $8.42 \pm 12.23^{\mathrm{b}}$ & 0.0323 & $3.20 \pm 7.34^{\mathrm{d}}$ \\
\hline $\mathrm{SE} \pm$ & 8.415 & & 0.367 \\
\hline
\end{tabular}

Mean with the same letters along the same column are not significant different from each other $(P>0.05)$

\section{CONCLUSION AND RECOMMENDATION}

\section{Conclusion}

The results of the Indian jujube (Ziziphus mauritiana) seed pre-germination treatment showed that mechanically scarified method improved seed germination. Therefore, Mechanical scarification can be concluded to be the best method of breaking dormancy in Z. mauritiana which resulted in an increased germination percentage of 95.20 \pm 7.34 .

\section{Recommendation}

Based on the results above it is recommended that for easy multiplication of seedlings of Z, mauritiana for plantations establishment the nursery workers should adopt the use of mechanical scarification method as a pre-sowing treatment to promote and enhance better germination of the species. 


\section{REFERENCES}

1. Danthu, A., Roussel, J., \& Saar, A. (1992). Effect of Different Pretreatment on the Germination of Acacia senegal seeds. Seed Science and Technology. 20(1):111-11.

2. Dogon-daji, A. (2002). Effects of Pre sowing Treatment on Seed Germination of Three Indigenous Tree Species in SemiArid Environment. M. Sc. Dissertation (unpublished). UDU Sokoto, Nigeria. 59.

3. Nwoboshi, L. C. (1982). Principles of Tropical Silviculture and Techniques. Oxford University press, Ibadan, Nigeria. 210.

4. Ajiboye, A. A., \& Agboola, D. A. (2008). Effect of Seeds Size and Phyto -hormone on the Germination of Seeds of Two Forest Trees Species, Prosopis africana (Gull) and Dialium guineensis (Wild). Proceedings of Third Conference on Science and National Development. 3: 145-150.

5. Luna, T., Wikinson, K., \& Dumroese, R. K. (2009). Seed Germination and Sowing Options In: Dumroese, R. K., Luna, T., \& Landis (Eds.). Nursery Manual for Native Plant: A guide for Tribal Nuseries.Vol.1: Nursery Management Agriculture Hand Book 730. Washington, D.C: US Department of Agriculture, Forest Service. 133-151.

6. Agboola, D. A. (1996). Effect of Storage Humidity on Seed Longevity and Sowing Depth on Seed Germination of Prosopis africana (Gull \&Perr.) Taub. Bangladesh Journal of Forest Science. 25(1\&2): 65-70.

7. Orwa, C., Mutua, A., Kindt, R., Jamnadass, R., \& Anthony, S. (2009). Agroforestry Database: A tree Reference and Selection Guide Version 4.0. World Agroforestry Centre, Kenya. 54.

8. US Forest Service. (2013). Ziziphus mauritiana Lam. Pacific Island Ecosystems at Risk (PIER).United States Forestry Service Data Base.

9. Ecocrop. (2013). Ecocrop database. Food and Agriculture Ogarnisation (FAO), Rome, Italy. 56.

10. Morton, J. F. (1987). Indian jujube. In: Fruits of Warm Climates. Florida Flair Books, Miami, United States of American. 272-275.

11. Latiff, A. M. (1991). Ziziphus mauritiana Lamk. Record from Proseabase. Verheij, E. W. M., \& Coronel, R. E. (Editors). PROSEA (Plant Resources of South-East Asia) Foundation, Bogor, Indonesia. 63.

12. Azam-Ali, S., Bonkoungou, E., Bowe, C., DeKock, C., Godara, A., \& Williams, J. T. (2006). Ber and other jujubes. In: Williams (Eds.), International Centre for Underutilized Crops, Southampton, UK. 67.

13. Sanon, H. O., \& Sanou, S. (2012). Effect of natural browse fodder availability on feeding behaviour of goats. Livestock Research for Rural Development, 24(11):205.

14. Nair, P. K. R. (1993). An Introduction to Agroforestry. Kluwer Academic Publishers in Collaboration with International Centre for Research in Agroforestry (ICRAF). 41.

15. Collinson, A. (1988). Introduction to Word Vegetation. Published by Unwin Hyman (2nd eds.) London, United Kingdom. 325 .

16. Abubakar, M. (2002). Effects of Mycorrhiza and Watering Regime on Acacia Senegal (Linn) Wild in Semi-Arid Environment. M.Sc. Dissertation (Unpublished). UDU Sokoto, Nigeria. 73.

17. Otegbeye, G. O., Owonubi, J. J., \& Oviasuyi, P. K. (2001). Interspecific variation growth of Eucalyptus growing in northern Nigeria. In Proceeding of 27th Annual conference of Forest Association, Nigeria (pp. 12-16).

18. Sodimu, A. I., Onwumere, G. B., \& Yilwa, V. M. (2019). Soil based heavy metals originating from anthropogenic activities on floristic composition of some selected sites in Kaduna Northern Guinea Savanna of Nigeria. Asian Journal of Environment \& Ecology, 1-10.

19. Steel, R. G. D., \& Torrie, J. H. (1980). Principles and Procedure of Statistics. McGraw-Hill Book Co. Inc: New York. USA. 356.

20. Duguma, B., Kang, B. T., \& Okali, D. U. (1998) Factors Affecting Germination of Leuceana leucophala seed. Science and Technology. 16:489-500

21. Gill, L. S., Onyibe, H. I., \& Asemota, B. P. (2006). Studies on the germination of Calliandraportoricensis (Benth). The Nigerian Journal of Forestry, 22, 53-57.

22. Owonubi, J. J., Otegbeye, G. O., \& Nwokedi, C. (2005). Development of pre-germination technique for Azadirachta indica: preliminary investigation. In Sustainable Forest Management in Nigeria: Lessons and Prospects (Proceedings of the 30th Annual Conference of the Forestry Association of Nigeria, Held in Kaduna, Kaduna State (pp. 29-38).

23. Ibrahim, A., \& Otegbeye, G. O. (2004). Methods of achieving optimum germination in Adansonia digitata. Bowen journal of Agriculture, 1(1), 53-60.

24. Aduradola, A. M., Adeola, B. F., \& Adedire, M. O. (2005). Enhancing germination in seeds of African star apple, Chrysophyllum albidum (G. Don). Journal of food, agriculture \& environment (JFAE). 3:285-287.

25. Adio, A. F., Odigie, G. A., \& Imran, G. T. (2006). The influence of pre-treatments on germination of seeds of Adansonia digitata (Baobab). Journal of Forestry Research and Management, 3, 27-33.

26. Dachung, G., \& Verinumbe, I. (2006, November). Effects of water and acid pre-treatment on the germination of Prosopis africana seeds. In Proceedings of the 31st Annual Conference of the Forestry Association of Nigeria, Makurdi (pp. 11-18).

27. Agbogidi, O. M., Bosah, B. O., \& Eshegbeyi, O. F. (2007). Effects of acid pre-treatment on the germination and seedling growth of African Pear (Dacryodes edulis Don. G. Lam. HJ). Int. J. Agric. Res, 2(11), 952-958.

28. Teklehaimanot, Z., Tomlinson, H., Ng'andwe, M., \& Nikiema, A. (2000). Field and in vitro methods of propagation of the African locust bean tree (Parkia biglobosa (Jacq.)(Benth.). The Journal of Horticultural Science and Biotechnology, 75(1), 42-49.

29. El-Nour, M., El-Khalifa, K., Massimo, K., \& ElHassen, B. (1991). Preliminary Study on Seed Pre - germination. 23. 